Article

\title{
How Did the Late 1980s Climate Regime Shift Affect Temperature-Sensitive Fish Population Dynamics: Case Study of Vendace (Coregonus albula) in a Large North-Temperate Lake
}

\author{
Külli Kangur * ${ }^{\circledR}$, Kai Ginter, Andu Kangur ${ }^{\dagger}$, Peeter Kangur and Tõnu Möls ${ }^{\dagger}$ \\ Centre for Limnology, Institute of Agricultural and Environmental Sciences, Estonian University of Life Sciences, \\ 61117 Rannu, Estonia; kai.ginter@keskkonnaamet.ee (K.G.); pk@pyhajarve.edu.ee (P.K.) \\ * Correspondence: kylli.kangur@emu.ee; Tel.: +372-5246085 \\ + The two co-authors have passed away and however their great contribution to the development of this \\ manuscript needs to be acknowledged as co-authors.
}

Received: 30 July 2020; Accepted: 23 September 2020; Published: 26 September 2020

\begin{abstract}
The population dynamics of fish in northern lakes is strongly influenced by climatic factors. In this study, we investigated whether there is a link between the late 1980s climate regime shift in Europe and the collapse of vendace (Coregonus albula) population at the same time in Lake Peipsi. Until the end of the 1980s, vendace was very abundant in the lake, but then its catches sharply declined. This decline inspired investigations into the extreme weather events preceding the vendace collapse using data on daily water temperatures and ice phenology together with commercial fishery statistics since 1931 and test catch data since 1986. We identified using advanced statistical methods that the hot summer of 1988, which was accompanied by a severe cyanobacterial bloom and extensive fish kill, and the subsequent non-permanent ice cover and early ice-offs in 1989 and 1990 in Lake Peipsi were the main reasons for the disappearance of vendace from catches in 1991. Moreover, a negative correlation appeared between catches of the predatory pikeperch (Sander lucioperca) and vendace. Predation pressure as well as fish habitat degradation caused by lake eutrophication may contribute to the instability of the vendace population too. Our study showed that extreme weather events such as heat waves in summer and non-permanent ice-cover in winter in consecutive years may have long-lasting harmful effects on the population abundance of cool-water fish species such as vendace whose eggs usually develop under an ice cover in north-temperate lakes.
\end{abstract}

Keywords: climate regime shift; extreme weather events; phenology of lake ice; population dynamics of vendace; predator-prey interactions

\section{Introduction}

Declines and collapses of fish populations have frequently been attributed to local human interventions, including over-exploitation of fisheries [1-4] and habitat loss due to pollution [5]. Additionally, predator-prey interactions [6], parasite infections [7] and climate can trigger the reduction of fish species. Although natural factors are not frequently reported to cause the collapse of fish populations [8-10], climate may influence fish populations through a variety of direct and indirect processes [11,12]. The impact of abrupt climatic shifts on lake ecosystems will likely differ from the effects of long-term gradual warming [13].

Decline and collapse of fish populations at different geographical scales have been widely reported in recent decades $[2,9,14]$. In Europe's fourth largest lake, Lake Peipsi (Estonia/Russia), vendace (Coregonus albula) was the dominant fish species and the main target of commercial fishery until the end 
of the 1980s; however, it dramatically declined thereafter. Similarly, vendace abundance has declined in Finland (e.g., Lake Pyhäjärvi and Lake Puulavesi [15-17]), Sweden (Lake Mälaren [18]) and the United Kingdom (Lake Bassenthwaite; $[19,20]$ ). However, in the northern distribution area of vendace, such as Finland, the stock has recovered and fish are abundant [21].

Vendace is a typical lacustrine coregonid occurring principally in northern European freshwater ecosystems [22,23]. It is a small-bodied shoaling pelagic fish that prefers cold water (e.g., [18,24-26]). Adult vendace avoid areas where the temperature exceeds $18-19^{\circ} \mathrm{C}$ or the concentration of oxygen is less than $2 \mathrm{mg} \mathrm{L}^{-1}[19,23,27,28]$. Vendace has a cold-water thermal window characterized by a metabolic optimum approximately 7-9 ${ }^{\circ} \mathrm{C}$ [29-31]. According to Potapova [32], vendace feeds most intensively at $15-16{ }^{\circ} \mathrm{C}$, and the intensity of its feeding drops when the temperature rises to $18-20^{\circ} \mathrm{C}$. In Estonian waters, vendace spawns in November to December at a temperature of $0.2-3{ }^{\circ} \mathrm{C}$ and hatching takes place in the middle of April [33]. In Lake Peipsi, vendace attains sexual maturity at the age of two years and has a typical lifespan of only 3-5 years [34].

Due to its preference for cold water and its peculiar life history, such as autumn spawning, short lifespan and early reproduction $[26,35,36]$, vendace populations are very vulnerable to habitat changes and have substantially fluctuating abundances [16]. The literature reports that high water temperatures [29,30], low oxygen levels $[19,23,28]$ and variability of ice conditions $[18,37]$ may have negative effects on vendace populations. Additionally, co-occurring stressors, for instance long-term eutrophication [38], fishing pressure [36] and predator-prey interactions [39-42], may deepen the effect of climate change on the year-class strength and population dynamics of vendace [14].

Although many complex interactions may cause reduction in the abundance of species, the potential effects of such interacting components of the global climate change on biotic communities remain poorly elucidated [11,43-45]. Moreover, the effects of extreme weather events on ecosystems are much less understood than the effects of longer-term changes in average environmental conditions [46], and there is a pressing need to extend current understanding of abrupt changes in ecological systems as climate warming accelerates [47]. Therefore, analyzing the long-term population dynamics of vendace and coupling the results with data on climatic factors, water quality and fish community features in Lake Peipsi could contribute new knowledge about the factors affecting the decline and collapse of fish populations in the north temperate region.

In the present study, we used vendace as a biological model to study the relationship between climate regime shift and population collapse. Other sensitive cool-water fish declining in the lake (e.g., burbot Lota lota and Peipsi whitefish Coregonus lavaretus maraenoides) are longer-lived than vendace and likely to respond more slowly to environmental change. We used a nearly nine-decade dataset on vendace commercial catches and lake surface water temperature (LSWT) parameters with the aim of clarifying the relationships between extreme weather events related to the late 1980s regional climate regime shift $[48,49]$ and vendace catch dynamics in Lake Peipsi. The specific focus of our study was to identify the environmental variables most related to the collapse of the vendace population in Lake Peipsi by the turn of the 1980/1990 decade. We hypothesized that the drastic reduction of the vendace population and catches was linked to the cumulative effects of warm water temperature extremes and fish kills during heat waves in summer and the extreme ice conditions in winter during the years before the disappearance of vendace from the commercial fish catches. We investigated the differences in environmental conditions between the three consecutive years immediately preceding the collapse and the "ordinary" years since the 1930s. Additionally, the potential influences of the flourishing pikeperch (Sander lucioperca) population, the high fishing pressure and continued cultural eutrophication of Lake Peipsi [50,51] on the vendace stock were discussed. 


\section{Material and Methods}

\subsection{Study Area}

Lake Peipsi $\left(57^{\circ} 51^{\prime}-59^{\circ} 01^{\prime} \mathrm{N} ; 26^{\circ} 57^{\prime}-28^{\circ} 10^{\prime} \mathrm{E}\right)$ is the fourth largest lake in Europe, located south of the Gulf of Finland on the border of Estonia and Russia (Figure 1). Peipsi is a polymictic and shallow lowland lake (Table 1) with a surface area of $3555 \mathrm{~km}^{2}$ and a mean water level of $30 \mathrm{~m}$ above sea level. In fact, Lake Peipsi, which is elongated more than $150 \mathrm{~km}$ in the north-south direction, is a lake system, consisting of three limnologically different parts: Lake Peipsi s.s. (mean and maximum depth 8.3 and 12.9 m, respectively), Lake Lämmijärv (2.5 and $15.3 \mathrm{~m}$ ) and Lake Pihkva (3.8 and 5.3 m). Lake Peipsi's water level is not regulated; however, natural water level fluctuations are considerable, with an overall range of $3.04 \mathrm{~m}$ over the last 80 years and a mean annual range of $1.15 \mathrm{~m}$ [52]. Situated in the north temperate region, in the transition zone between a maritime and continental climate, Lake Peipsi is characterized by variable weather conditions. The lake is normally covered with ice from December to April, but, in recent years, the onset of ice cover and melt-off have varied substantially. The winter 2019/2020 was the first winter since the beginning of the observation history in 1921 when there was no permanent ice cover on Lake Peipsi [53]. Due to the lake's large surface area and its relative shallowness, waves affect the bottom during the ice-free period, and temperature stratification is therefore usually short and unstable. Stratification may occur only in the case of calm and windless days.

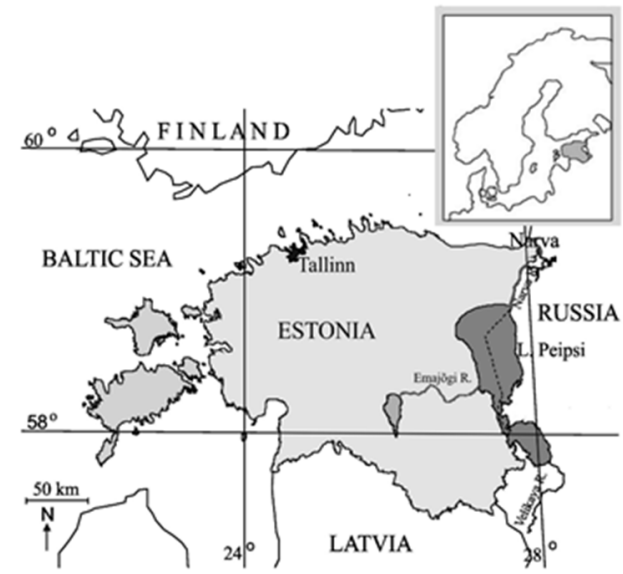

Figure 1. Location of Lake Peipsi.

Table 1. Selected characteristics of Lake Peipsi at a mean water level of $30 \mathrm{~m}$ above sea level (after Jaani [52]). Nutrient (surface water 0-1 m), chlorophyll $a$ (integral sample) and water transparency values are presented as arithmetic means with minimum and maximum of measured values (in brackets). All estimates correspond to the open water period (May-October) during 2010-2019.

\begin{tabular}{cc}
\hline Location & $\mathbf{5 7}^{\circ} \mathbf{5 1}^{\prime} \mathbf{- 5 9 ^ { \circ } \mathbf { 0 1 }} \mathbf{~} \mathbf{~}$ \\
$\mathbf{2 6}^{\circ} \mathbf{5 7}^{\prime} \mathbf{- 2 8}^{\circ} \mathbf{1 0}^{\prime} \mathbf{~ E}$ \\
\hline Drainage area $\left(\mathrm{km}^{2}\right)$ & 47,800 \\
Lake area $\left(\mathrm{km}^{2}\right)$ & 3555 \\
Volume $\left(\mathrm{km}^{3}\right)$ & 25.07 \\
Mean depth $(\mathrm{m})$ & 7.1 \\
Maximum depth $(\mathrm{m})$ & 15.3 \\
Hydrological turnover time (year) & 2 \\
Total phosphorus $\left(\mathrm{mg} \mathrm{P} \mathrm{m}^{-3}\right)$ & $54(13-220)$ \\
Total nitrogen $\left(\mathrm{mg} \mathrm{N} \mathrm{m}^{-3}\right)$ & $748(250-2100)$ \\
Chlorophyll $a\left(\mathrm{mg} \mathrm{m}^{-3}\right)$ & $29(4-117)$ \\
Secchi disc water transparency $(\mathrm{m})$ & $1.4(0.4-3.8)$ \\
Trophic status [54] & eutrophic \\
\hline
\end{tabular}


At present, the whole lake is eutrophic (Table 1), with a clear south-north gradient. The northern and deeper part is significantly poorer in nutrients than the southern, very shallow part [50]. Differences in water quality between the northern and southern parts of the lake (polarity) are caused by the differences in natural environmental conditions and by the anthropogenic impacts of the local human population $[10,51]$.

Lake Peipsi is of great social and economic significance due to the importance of fishery, which is a substantial sector of rural employment in the Peipsi region and an essential part of life in its coastal villages. Lake Peipsi is inhabited by 37 fish species [55]; no species have disappeared over the past century, and invasion of new species has not been recorded either. Additionally, there have not been significant stockings of fish during that time period. Lake Peipsi has been historically rich in fish production [56], but, even though the species composition and inter-annual variations are as before, the commercial fish catch has over the years declined to about half the size of the catch ninety years ago [57]. Moreover, there have been shifts in relative abundances of key fish species both in commercial catches as well as in experimental trawl samples, including the decrease of the vendace population and the increase of the pikeperch population (Table 2).

Table 2. Species composition and annual commercial catches according to fishery statistics from 1986 and 1998-2012 and average catch per unit effort (CPUE; kg per trawl-hour) of trawl samples taken in autumn during the same years in Lake Peipsi.

\begin{tabular}{ccccc}
\hline \multirow{2}{*}{ Fish Species } & \multicolumn{2}{c}{ Commercial Catch $\mathbf{( 1 0} \mathbf{~ k g )}$} & \multicolumn{2}{c}{ Trawl Samples Catch (kg) } \\
\cline { 2 - 5 } & $\mathbf{1 9 8 6}$ & $\mathbf{1 9 9 8 - 2 0 1 2}$ & $\mathbf{1 9 8 6}$ & $\mathbf{1 9 9 8 - 2 0 1 2}$ \\
\hline Pikeperch Sander lucioperca & $75(0.8 \%)$ & $1542(25.1 \%)$ & $5.4(1.4 \%)$ & $61.1(28.5 \%)$ \\
Smelt Osmerus eperlanus & $1556(15.9 \%)$ & $860(14 \%)$ & $15.9(4.1 \%)$ & $1.9(0.9 \%)$ \\
Common bream Abramis brama & $610(6.2 \%)$ & $1037(16.9 \%)$ & $169.7(43.7 \%)$ & $66.0(30.9 \%)$ \\
Eurasian perch Perca fluviatilis & $1267(12.9 \%)$ & $1101(17.9 \%)$ & $92.1(23.7 \%)$ & $40.3(18.8 \%)$ \\
Roach Rutilus rutilus & $732(7.5 \%)$ & $757(12.3 \%)$ & $40.5(10.4 \%)$ & $17.9(8.4 \%)$ \\
Ruffe Gymnocephalus cernuus & $2842(29 \%)$ & $473(7.7 \%)$ & $28.2(7.3 \%)$ & $13.2(6.2 \%)$ \\
Northern pike Esox lucius & $426(4.3 \%)$ & $232(3.8 \%)$ & $6.3(1.6 \%)$ & $8.8(4 \%)$ \\
Burbot Lota lota & $113(1.2 \%)$ & $48(0.8 \%)$ & $1.0(0.3 \%)$ & $1.8(0.8 \%)$ \\
Vendace Coregonus albula & $2084(21.2 \%)$ & $16(0.3 \%)$ & $26.9(6.9 \%)$ & $0.018(0.007 \%)$ \\
Peipsi whitefish Coregonus lavaretus & $106(1.1 \%)$ & $15(0.2 \%)$ & $1.1(0.3 \%)$ & $0.04(0.02 \%)$ \\
Other fish species & $4(0.0 \%)$ & $55(1 \%)$ & $0.9(0.2 \%)$ & $2.8(1.3 \%)$ \\
Total & $9815(100 \%)$ & $6136(100 \%)$ & $387.9(100 \%)$ & $213.7(100 \%)$ \\
\hline
\end{tabular}

\subsection{Sampling and Dataset}

To characterize long-term changes in the key fish populations of Lake Peipsi, we analyzed fish species composition and relative abundance of different fish species in the commercial catches in relation to environmental variables. Proper data from fish stocks beyond the past 90 years are lacking. The commercial fisheries statistics of Lake Peipsi, collected from fishermen by the state authorities, exist for the periods 1931-1940 (Soviet Union and Estonia) and 1950-2019 (Soviet Union, followed by Russia and Estonia). The period 1941-1949 is not covered due to World War II. The fish data are based on catches using a variety of fishing gear in different time periods and localities. Information on the main changes in fishing gear and fishing effort since the 1930s can be found in the work by Kangur et al. [58]. The basic fishing gear used in Lake Peipsi was the local modifications of fence traps for the catch of vendace, lake (dwarf) smelt (Osmerus eperlanus m. spirinchus) and Eurasian perch (Perca fluviatilis), supplemented by gill nets for the catch of pikeperch, Northern pike (Esox lucius) and common bream (Abramis brama). Bottom seining is also employed, mostly for the catch of pikeperch and perch.

Data on experimental trawl samples in Lake Peipsi since 1986 were collected by the authors and were mainly used for controlling the reliability of the commercial fishery statistics. 
Daily data on LSWT in Lake Peipsi are available at the Mustvee hydrometric station $\left(58^{\circ} 50^{\prime} \mathrm{N}\right.$, $26^{\circ} 57^{\prime}$ E) from 1924 onwards. At the hydrometric station the LSWT in the near shore waters was measured using a Celsius mercury thermometer twice in $24 \mathrm{~h}$ at 8 a.m. and at 8 p.m. at a depth of $10 \mathrm{~cm}$ [52]. Since May 2009, an automatic station (VAISALA, MAWS110 and water temperature sensor QMT110) was used every hour for LSWT measurements. Daily values of LSWT in Lake Peipsi were obtained from the Institute of Meteorology and Hydrology of the Estonian Ministry of Environment and later, since 1 June 2013 from the Estonian Weather Service of the Estonian Environment Agency.

\subsection{Data Analysis}

We used the GLM procedure in SAS [59] with a cubic polynomial model to analyze long-term changes in LSWT. To make calculations simpler without reducing the model prediction accuracy, the year numbers (1924-2010) were linearly scaled to change between 0.4 and 9 (subtracting 1920 from the specific year number, e.g., 2010, and thereafter dividing the result by 10 ). The $95 \%$ confidence limits for the parameter values were estimated, assuming normality of model residuals [59,60]. Altogether 32 temperature parameters were formed to characterize the LSWT pattern of a year. The pre-determined temperature parameters "lowlevel" and "highlevel" were set to 1 and $17^{\circ} \mathrm{C}$, respectively, with $17^{\circ} \mathrm{C}$ being chosen as the high temperature limit due to the declining intensity of vendace feeding when the temperature rises to $18-20{ }^{\circ} \mathrm{C}$ [32]. Both ice formation and melt-off in Lake Peipsi may last 2-3 weeks but can take up to a month. Therefore, we assumed the duration of the ice-covered period to be conventionally equal to the number of days when the temperature was $<1{ }^{\circ} \mathrm{C}$ ("lowlevel"). A year's LSWT dynamics were characterized using the following parameters: beginning date of the ice-off period ("ice-off date", LSWT $\geq 1{ }^{\circ} \mathrm{C}$ ); beginning date of ice-covered period ("ice-formation date", LSWT $\leq 1^{\circ} \mathrm{C}$ ); maximum LSWT of a year ("maxtemp"); the first day when LSWT exceeded $17^{\circ} \mathrm{C}$ ("firsthightempday"); and the number of days when LSWT exceeded $17^{\circ} \mathrm{C}$ ("highdays"). Mean LSWT was calculated for the whole ice-free period (LSWT $\geq 1{ }^{\circ} \mathrm{C}$ ); for a high-temperature period (LSWT $\geq 17^{\circ} \mathrm{C}$ ); and for fixed seasonal time periods (e.g., 1-100, 100-130 Julian days of a year, etc.).

To identify factors possibly related to the changes in vendace abundance, 256 LSWT parameters of the current year and also of the preceding seven years, covering about twice the average lifespan of vendace in Lake Peipsi, were used (i.e., altogether 8 years in each year 32 LSWT parameters: $8 \times 32=256$ ). The most influential LSWT parameters were determined with the stepwise selection algorithm available in the SAS/REG procedure. We called the LSWT parameters that remained in the model the key parameters.

After the selection of key parameters, we applied Type 3 mixed ANOVA provided by the SAS/MIXED procedure to estimate the quantitative effects of selected parameters on vendace catch ratio $(\Delta)$ with the maximum likelihood method. The value of $\Delta$ was assigned to the current year:

$$
\Delta=\log _{2} \frac{\text { vendace catch in the current year }}{\text { vendace catch in the previous year }}
$$

Compared to reported fish catches, $\Delta$ is a ratio of catches and therefore less sensitive to occasional changes in catch registration methods, fishing gear types and fishing intensity. $\Delta$ increases/decreases by 1 if the vendace catch in the current year is two times larger/smaller than in the previous year. $p$-values were increased to take into account the multiple selection procedure of significant LSWT parameters (Bonferroni correction).

Differences between the LSWT parameters in the three consecutive years (1988-1990) preceding the collapse of the vendace population and other "ordinary" years since the 1930s were estimated using ANOVA and Tukey's test to determine whether these consecutive years with unfavorable conditions for vendace were an exception.

To analyze the reliability of the commercial catch data, we estimated the agreement between the commercial and trawl sample data by polynomial regression analysis and considered the logarithmic commercial catch of different species to be the dependent variable and the corresponding trawl 
sample data to be the predictor variable (factor). The potential influence of other factors such as continued cultural eutrophication on the collapse of vendace stock was discussed on the basis previous analyses $[9,57]$.

Finally, the Spearman correlation analysis was applied to correlate the catches of vendace with the catches of other key fish species (pikeperch, bream, burbot, perch and pike) in the same year and in the seven previous years in Lake Peipsi. $p$-values were decreased to take into account multiple analyses (Bonferroni correction). In the statistical tests, the level of significance $(\alpha)$ was set to 0.05.

\section{Results}

\subsection{Variation of Ice Phenology and Lake Surface Water Temperature}

During 1924-2010, the beginning of the ice-covered period ("ice-formation date") varied by more than two months, between 311 and 364 Julian days of a year, with a significant trend towards later ice formation during the last two decades (Table 3). Moreover, there was a significant long-term downtrend in ice-off dates (LSWT $\geq 1^{\circ} \mathrm{C}$ ) since the 1920s (Table 3 and Figure 2b). Ice-off dates occurred significantly earlier than had occurred previously. During 1924-2010, the mean "ice-off date" was the 103rd Julian day (early April), and the earliest ice-off dates occurred in 1990 (80th Julian day) and in 1989 (88th Julian day) (Table 3), the two years immediately preceding the disappearance of vendace in commercial catches in 1991 (Figure 3).

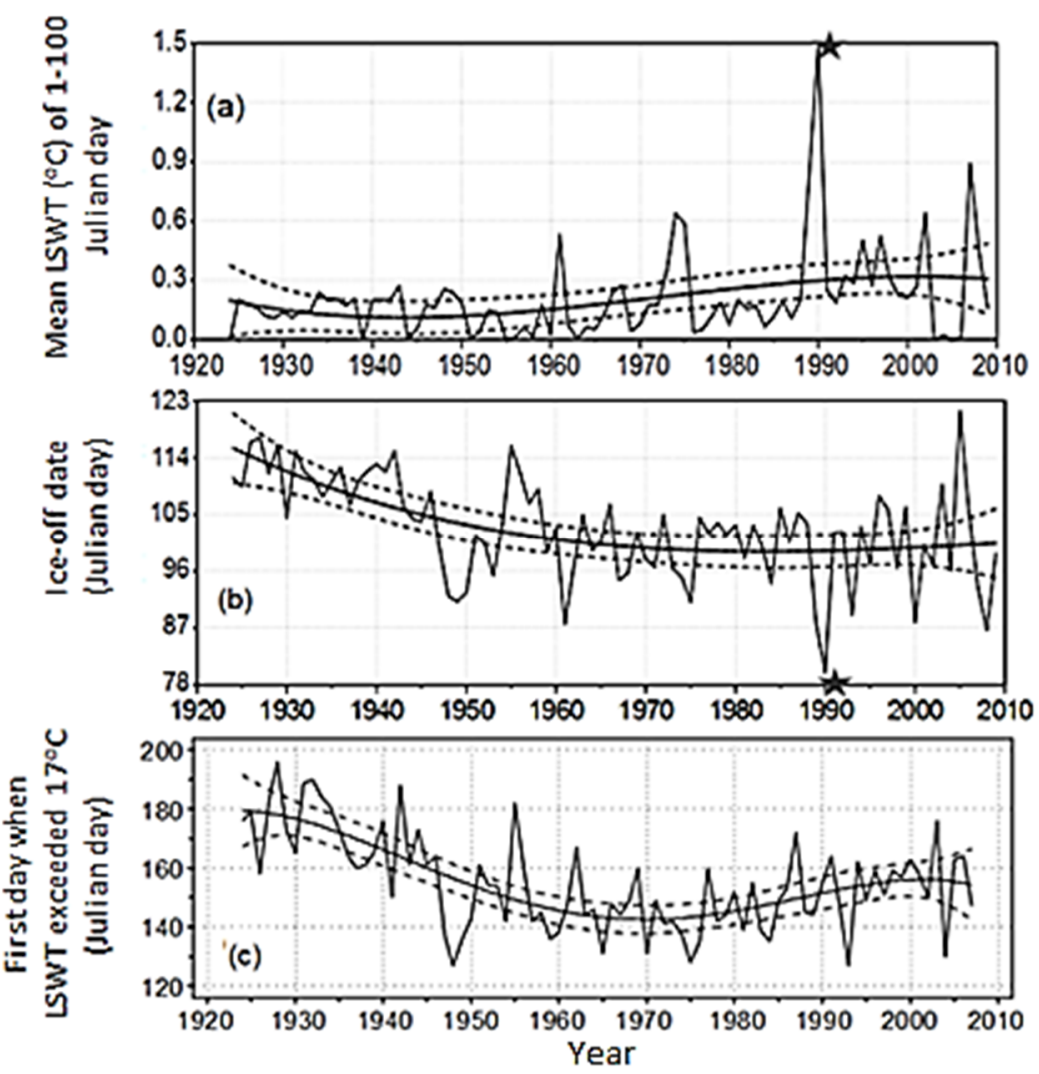

Figure 2. Long-term changes of selected lake surface water temperature (LSWT) parameters in Lake Peipsi: (a) mean LSWT $\left({ }^{\circ} \mathrm{C}\right.$ ) of 1-100 Julian days; (b) ice-off date-first Julian day when LSWT exceeded $1{ }^{\circ} \mathrm{C}$; and (c) first day when LSWT exceeded $17^{\circ} \mathrm{C}$ (Julian day). Cubic regression curves predict the parameter values for different times (continuous line). The $95 \%$ confidence limits for predictions are shown by dashed lines. The regressions presented by lines are significant $\left(p<10^{-6}\right)$. The year of vendace collapse is marked with " $\star$ ". 
Table 3. Statistical characteristics of selected water temperature parameters for the periods 1930-1960, 1961-1985 and 1986-2010 and for the years of vendace collapse in Lake Peipsi.

\begin{tabular}{|c|c|c|c|c|c|c|c|c|c|c|c|c|c|c|c|c|}
\hline \multirow{2}{*}{$\begin{array}{c}\text { Temperature } \\
\text { Parameter }\end{array}$} & \multicolumn{4}{|c|}{ 1930-1960 } & \multicolumn{4}{|c|}{ 1961-1985 } & \multicolumn{4}{|c|}{ 1986-2010 } & \multirow{2}{*}{$\begin{array}{c}1988 \\
\text { Value }\end{array}$} & \multirow{2}{*}{$\begin{array}{c}1989 \\
\text { Value }\end{array}$} & \multirow{2}{*}{$\begin{array}{c}1990 \\
\text { Value }\end{array}$} & \multirow{2}{*}{$\begin{array}{l}1991 \\
\text { Value }\end{array}$} \\
\hline & Mean & Min & Max & $\mathrm{S}$ & Mean & Min & $\operatorname{Max}$ & S & Mean & Min & Max & S & & & & \\
\hline Ice-off date * (Julian day) & 107 & 91 & 117 & 1 & 100 & 88 & 107 & - & 101 & 87 & 121 & - & 104 & 88 & 80 & 102 \\
\hline Maxtemp $*\left({ }^{\circ} \mathrm{C}\right)$ & 22.7 & 17.8 & 28.4 & j & 25.3 & 22.3 & 28.0 & - & 24.6 & 20.6 & 28.8 & - & 28.8 & 26.7 & 25.3 & 26.4 \\
\hline Firsthightempday $\left(17^{\circ} \mathrm{C}\right) *($ Julian day $)$ & 163 & 127 & 196 & 1 & 145 & 128 & 167 & - & 156 & 127 & 194 & - & 145 & 144 & 155 & 164 \\
\hline Highdays $\left(\geq 17^{\circ} \mathrm{C}\right) *($ days $)$ & 64 & 8 & 107 & / & 84 & 46 & 102 & - & 79 & 48 & 110 & - & 90 & 91 & 81 & 77 \\
\hline Ice formation date (Julian day) & 331 & 311 & 361 & - & 331 & 311 & 362 & - & 333 & 312 & 364 & / & 311 & 326 & 325 & 339 \\
\hline Mean LSWT of 100-130 Julian days * & 3.76 & 0.62 & 8.42 & / & 5.96 & 2.98 & 9.46 & - & 5.97 & 0.0 & 9.19 & - & 3.85 & 9.71 & 12.8 & 5.90 \\
\hline
\end{tabular}

Mean, Min and Max-mean, minimum and maximum descriptive statistics for the indicated period; S, regression line slope; "I" and " $>$ " denote a significant parameter increase or decrease during the period $(p<0.005$ after Tukey-Kramer adjustment for multiple comparisons), "- marks periods when the change cannot be verified; * variables showing significant changes $\left(p<10^{-6}\right)$ in the form of a cubic polynomial regression over the whole period 1930-2010. 


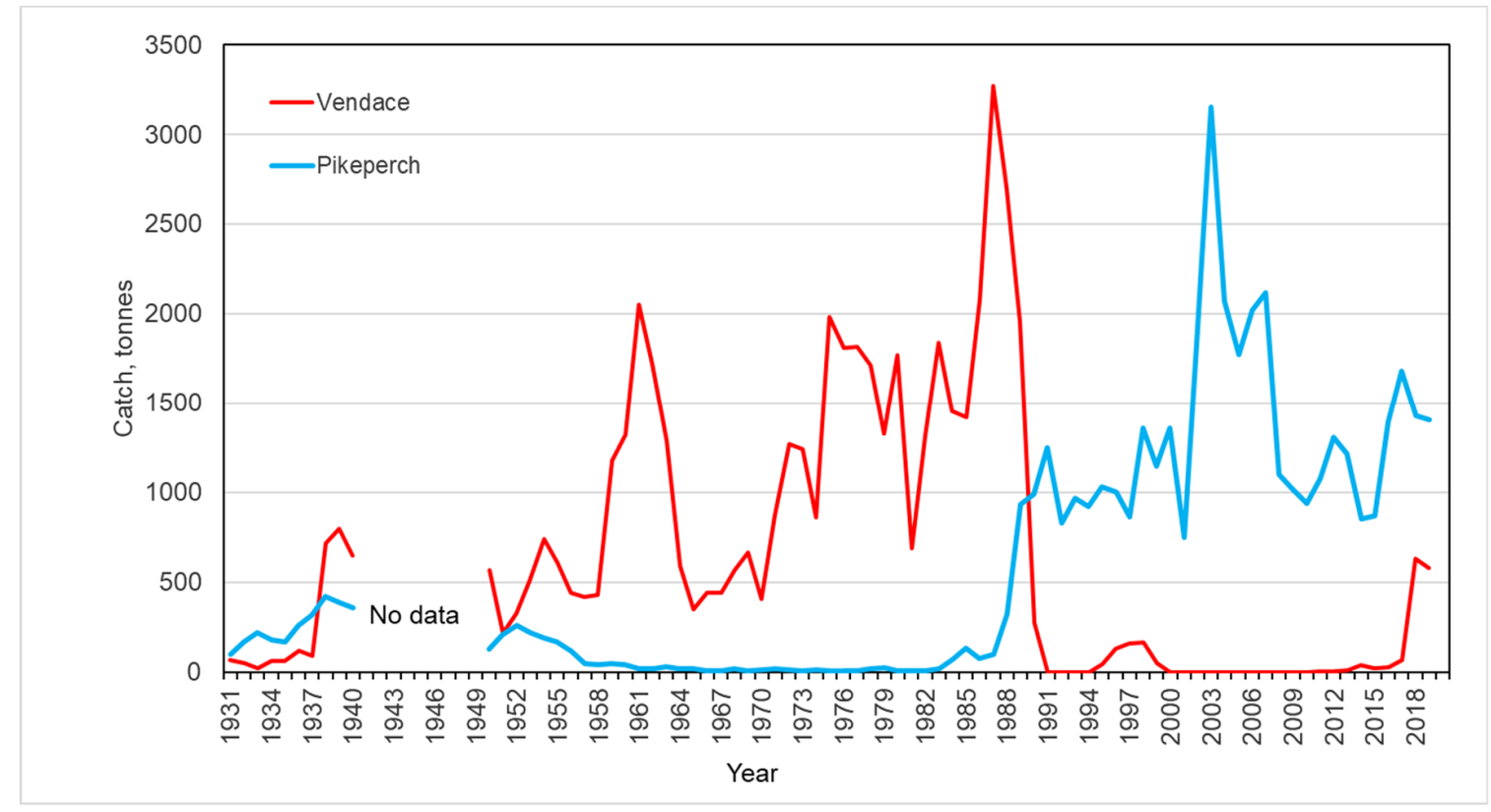

Figure 3. Commercial catches of vendace and pikeperch in Lake Peipsi during 1931-2019.

The LSWT pattern in the ice-free (open water) period showed considerable yearly variations. However, there was a significant $(p<0.0001)$ long-term downtrend in the date at which WT $\geq 17^{\circ} \mathrm{C}$ was reached in spring since the 1920s (Figure 2c). The duration of the high LSWT period, the number of LSWT $\geq 17^{\circ} \mathrm{C}$ days ("highdays"), the maximum LSWT of the year ("maxtemp") and the average LSWT in spring (100-130 Julian days) all significantly increased during the observation years (1924-2010; Table 3). An exceptionally high average LSWT of 1-100 Julian days was observed in 1990 (Figure 2a), the year before the disappearance of vendace in commercial catches (Figure 3).

During 1924-2010, the mean LSWT during the ice-free (LSWT $\geq 1{ }^{\circ} \mathrm{C}$ ) period was $12.6^{\circ} \mathrm{C}$, and the yearly maximum LSWT displayed large inter-annual variability, differing by more than $10^{\circ} \mathrm{C}$ (Table 3). The day of yearly highest LSWT commonly occurred in July, varying from the beginning of June to the end of August. The summer of 1988 was very hot with the highest LSWT $28.8^{\circ} \mathrm{C}$ (27 June 1988) in the whole observation period and with a period of WT $\geq 26^{\circ} \mathrm{C}$ lasting for two weeks, from 25 June to 7 July. In 1988, the mean LSWT of the ice-free period (LSWT $\geq 1{ }^{\circ} \mathrm{C}$ ) was also the highest $\left(15.0^{\circ} \mathrm{C}\right)$ recorded during the years under investigation. Three years after this extremely hot summer, vendace disappeared (Figure 3).

According to the ANOVA and Tukey's test, LSWT parameters in the three-year period (1988-1990) immediately preceding the collapse of the vendace population differed significantly from the "ordinary" years since the 1930s. During 1988-1990, the number of WT $\geq 17^{\circ} \mathrm{C}$ days ("highdays", 81-91 days) was significantly higher $\left(p<0.02, \mathrm{~F}_{1,85}=5.27\right)$ and the maximum LSWT was $3^{\circ} \mathrm{C}$ higher $(p<0.036$, $\left.\mathrm{F}_{1,85}=4.53\right)$ than the average values of the "ordinary" years. Moreover, the open water period lasted approximately 13 days longer during 1988-1990 than the mean open-water period $(p<0.017$, $\left.\mathrm{F}_{1,85}=5.84\right)$, and the beginning date of the ice-off period occurred approximately 24 days earlier $\left(p<0.04, \mathrm{~F}_{1,85}=4.11\right)$ during 1988-1990 than the average ice-off date in the other years under investigation. This shows that three consecutive years with unusually warm LSWT and early ice-off are extremely rare and have occurred only once in Lake Peipsi during the observation years. 


\subsection{Trends in Fish Catch and Variability of the Vendace Stock}

The results of trawl samples displayed the same trends of change in the fish populations as the commercial fishery statistics, a decline in catches. We found good agreement between the commercial fish catches and the trawl sample data when using the commercial catches of different fish species as the dependent variable and the corresponding trawl sample data as the predictor variable (regression analysis: $\left.r^{2}=0.77, p<0.0001\right)$. The Spearman correlation coefficient between the two datasets was 0.67 $(p=0.0011)$.

According to the commercial fishery statistics, in the 1930s the lake's annual fish yield was estimated as $33 \mathrm{~kg} \mathrm{ha}^{-1}$; in the 1980s average annual yield declined to $27 \mathrm{~kg} \mathrm{ha}^{-1}$; and during 2010-2019 yield further declined to $15 \mathrm{~kg} \mathrm{ha}^{-1}$. Smelt, vendace, pikeperch and perch have dominated commercial landings from Lake Peipsi at different time periods. In the 1930s, the commercial catches consisted mainly of smelt (43\% of total catch), roach (Rutilus rutilus) $(16 \%)$, perch $(7 \%)$, bream (7\%), pike (3\%) and vendace $(2 \%)$. In the late 1930 s, pikeperch became another important commercial fish in the lake (Figure 3). From the 1950s to 1970s, the catches of pikeperch decreased, but, in the late 1980s, the catches of pikeperch increased explosively (Figure 3). At that time, vendace was of great importance for commercial fishing in Lake Peipsi. Its stock and catches increased from the middle of the 20th century until the late 1980s (Figure 3), reaching 3271 tons (33\% of the total annual yield) in 1987. Vendace was lacking in commercial catches from 1991 to 1994, followed by a small recovery period from 1995 to 2000. From 1998 to 2012, the commercial catches were dominated by pikeperch (25\%), perch (18\%), bream (17\%), smelt (14\%) and roach (12\%) (Table 2), while Peipsi whitefish, burbot, European eel (Anguilla anguilla), rudd (Scardinius erythrophthalmus), ide (Leuciscus idus), tench (Tinca tinca) and white bream (Blicca bjoerkna) were occasionally recorded in the catches. Since 2001, vendace catches have declined dramatically. During 2007-2012, the mean catch of vendace was 2.6 tons, and, in the same period, only a few vendace specimens have appeared in the trawl samples. In the last years, vendace returned to the commercial catches with an average annual yield of 140 tons (2.5\% of the total annual yield) during 2010-2019. At the same time, the fish species most targeted for harvest included perch (31\%), bream (23\%), pikeperch $(22 \%)$ and roach $(10 \%)$.

\subsection{Water Temperature Parameters Related to Changes in Vendace Catch}

The stepwise regression analysis identified five key LSWT parameters to be significantly related (model $r^{2}=0.81, p<0.0001$ ) to the logarithmic vendace catch ratio $(\Delta)$ : high mean LSWT of the first 100 days of a year (of a year and five years earlier), late ice formation, late ice-off date and warm August. Thereafter, Type 3 mixed ANOVA was applied to identify the relationships between selected parameters, their co-effect and vendace catch ratio. The relatively high mean LSWT of the first 100 days of a year (Figure 2a) had a highly significant (estimated slope $=-1.23, p<0.0001$ ) negative effect on the vendace catch in the subsequent year. Additionally, late ice-off date (estimated slope $=0.44, p=0.03$ ) and warm August (estimated slope $=0.53, p=0.28$ ) were related to increased vendace catches after two years. Additionally, regression analysis proved that the change in the vendace catch may depend on these five selected LSWT parameters in general and not only in the exceptional years (Figure 4). However, the dependence of $\Delta$ on weather conditions is nonlinear (cubic). 


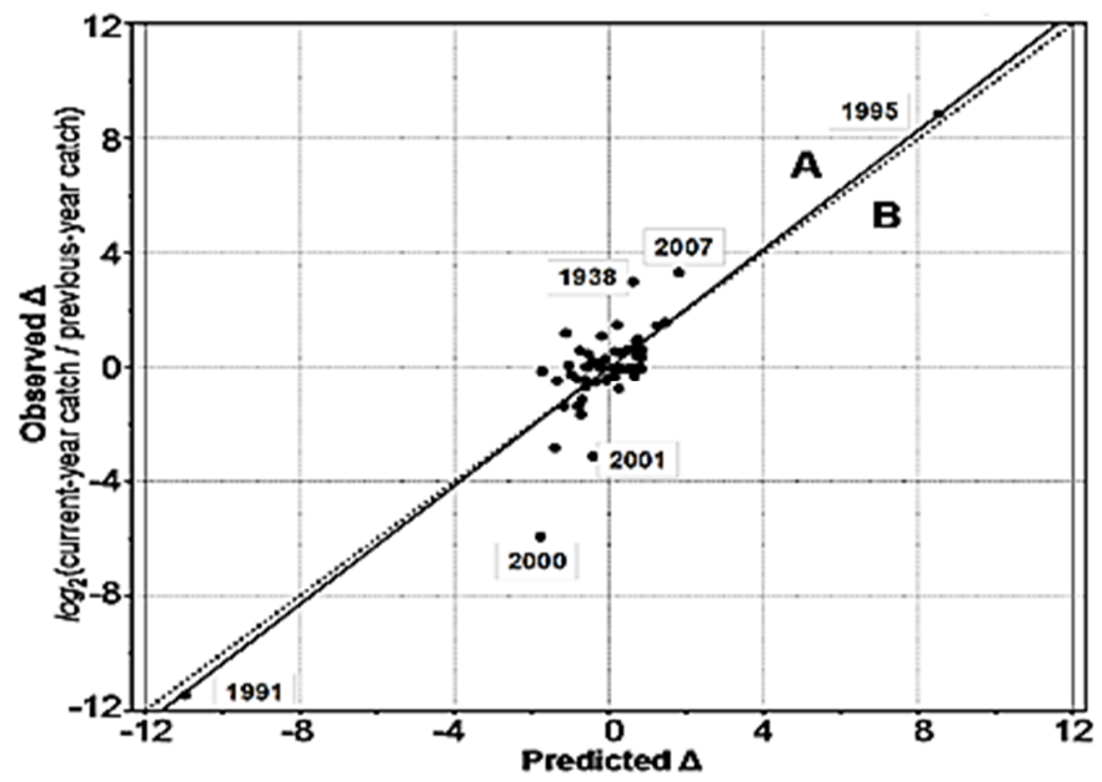

Figure 4. Observed change in logarithmic vendace catch ratio $(\Delta)$ compared to the change predicted on the basis of key LSWT parameters. Continuous line (A) fits all the data; dashed line (B) fits data excluding the years 1991 and 1995. The regression line (continuous line A) fits all the data, including data points of the years 1991 (collapse of the vendace population) and 1995 (small recovery). Nevertheless, the dashed line (B) fitted without using the 1991 and 1995 data $(p<0.0001)$ did not differ practically from line A.

\subsection{Correlations between Fish Species in Catches}

A significant increase in the pikeperch population preceded the collapse of vendace (Figure 3). Correlation analysis revealed a strong negative Spearman correlation of vendace catches with pikeperch catches in the same year and in seven previous years (Table 4). A significant negative correlation also appeared between catches of bream and vendace with a time lag of up to five years (Table 4). On the other hand, a positive correlation appeared between the catches of vendace and burbot, which are both late autumn and winter spawning cool-water fishes. A small positive correlation with a lag was also observed between the vendace catch and catches of perch and pike. The catches of vendace in subsequent years were self-evidently correlated.

Table 4. Spearman correlations between vendace catches and catches of other fish species in the current and the preceding seven-year period (time lag of 0-7 years).

\begin{tabular}{ccccccccc}
\hline Time Lag & $\mathbf{0}$ & $\mathbf{1}$ & $\mathbf{2}$ & $\mathbf{3}$ & $\mathbf{4}$ & $\mathbf{5}$ & $\mathbf{6}$ & $\mathbf{7}$ \\
\hline $\boldsymbol{N}$ & $\mathbf{6 8}$ & $\mathbf{6 6}$ & $\mathbf{6 4}$ & $\mathbf{6 2}$ & $\mathbf{6 0}$ & $\mathbf{5 8}$ & $\mathbf{5 6}$ & $\mathbf{5 4}$ \\
\hline Pikeperch & -0.67 & -0.70 & -0.75 & -0.75 & -0.74 & -0.74 & -0.75 & -0.70 \\
Bream & -0.46 & -0.48 & -0.49 & -0.52 & -0.53 & -0.48 & $-0.37^{*}$ & $-0.32^{*}$ \\
Burbot & 0.64 & 0.62 & 0.60 & 0.61 & 0.64 & 0.67 & 0.62 & 0.59 \\
Perch & $0.41^{\ddagger}$ & $0.40^{\ddagger}$ & $0.38^{\dagger}$ & $0.33^{*}$ & $0.28^{*}$ & $0.21^{*}$ & $0.06^{*}$ & $-0.02^{*}$ \\
Pike & $0.35^{\dagger}$ & $0.38^{\dagger}$ & $0.34^{*}$ & $0.25^{*}$ & $0.21^{*}$ & $0.15^{*}$ & $0.14^{*}$ & $0.11^{*}$ \\
Vendace & 1.00 & 0.89 & 0.74 & 0.59 & $0.46^{\ddagger}$ & $0.36^{*}$ & $0.30^{*}$ & $0.25^{*}$ \\
\hline
\end{tabular}

$N$ is the number of pairs used to estimate the correlation. All correlations are significant at $p<0.0001$ except for those marked by superscripts: ${ }^{*} p>0.01 ;+0.001<p<0.01 ; \ddagger 0.0001<p<0.001$. Correlations of vendace with smelt, roach and whitefish were not significant and are accordingly omitted.

\section{Discussion}

The results of our study provide strong evidence of a link between a sudden collapse of vendace in Lake Peipsi in the late 1980s and a regional climate regime shift $[13,49]$ which manifested itself in 
Estonia with a sharp warming in the late 1980s, mainly from the winter of 1988/1989 with coherent shift in air temperature, snow cover duration and specific runoff [48]. Our findings highlight the role of both summer and winter environmental conditions in controlling vendace abundance. We show that extreme weather events in summer (intense heat waves) and winter (extreme ice conditions) in consecutive years may have long-lasting harmful effects on the population abundance of cool-stenothermal and oxygen-demanding fish species such as vendace in large shallow lakes in the north temperate region. Our study indicates that vendace, a small shoaling pelagic fish, reacts strongly and quickly to environmental extremes. A relatively short lifespan (in Lake Peipsi approximately three years) together with early reproduction, high fecundity and autumn spawning make the vendace population unstable and vulnerable to extraordinary changes in the environment. In Lake Peipsi, the highest LSWT $\left(28.8^{\circ} \mathrm{C}\right)$ during the whole observation period was measured in the extremely hot summer of 1988. Moreover, a two-week period with extraordinarily high LSWT $\left(\geq 26^{\circ} \mathrm{C}\right)$ occurred, which was accompanied by an extensive cyanobacterial bloom dominated by Planktothrix agardhii [61] and extensive fish kill [57]. During this period, shallow but usually well-mixed Lake Peipsi was probably an unfavorable habitat for vendace through the combined effects of increased water temperature and decreased oxygen concentrations leading to absence of cool-water refuges. According to Elliott and Bell [19], vendace avoid areas with a water temperature $>18{ }^{\circ} \mathrm{C}$ or oxygen concentration $<2 \mathrm{mg} \mathrm{L}{ }^{-1}$, and adult fish appear to be particularly sensitive to high temperatures and low oxygen concentrations. Thus, the extraordinarily high LSWT in 1988 in Lake Peipsi was probably lethal to many vendace adults. The vendace catch was still quite high in 1989 (Figure 3) probably because the survival of a large year-class 1988, a situation also described in Lake Puulavesi and other Finnish lakes [16,17].

Our results suggest that the success of the vendace population in Lake Peipsi also depends on ice conditions during spawning and early development. In 1989 and 1990, ice-off occurred particularly early, which was probably unfavorable for vendace recruitment. During incomplete ice cover, waves can reach the bottom and cause burial of vendace eggs in bottom sediments with consequent lack of recruitment. Our findings are consistent with a view that the temperature requirements for reproduction is a critical bottleneck in the life cycle of fish [62]. Moreover, diatom bloom and fish kill occurred immediately after the 1989 ice-off in Lake Peipsi [61]. Therefore, two years unsuitable for spawning probably decreased the recruitment rate significantly and thereby contributed to the collapse of vendace population, as the typical lifespan of vendace is only 3-5 years. Thus, we conclude that the collapse of the vendace stock in Lake Peipsi was probably related to the cumulative effect of extreme weather conditions in summer and winter in the three consecutive years 1988-1990, characterized by significantly unfavorable temperature and ice conditions exceeding the tolerance level of vendace.

Warmer springs and summers may also have positive effects on the vendace population due to advantageous feeding conditions. Our results indicate that the rapid warming of the water after early ice-off will have positive effects on vendace catch after a time lag. This seems to be related to favorable conditions for zooplankton development and, thereby, profitable food conditions for vendace fry; in Lake Peipsi, Daphnia and Bosmina species are particularly positively affected by warm spring water temperatures [63]. Nyberg et al. [18] suggested possible match between the spring development of zooplankton and the year-class strength of vendace in Swedish lakes. Similarly, in the Finnish Lake Pyhäjärvi, Helminen et al. [64] found that warm August temperatures had a positive influence on the vendace population due to the fact that warmer weather is accompanied by higher zooplankton abundance and that the food consumption of vendace is highest in August. Although the availability of suitable prey in spring and summer is an important factor, advantageous food conditions may not be realized when preceded by unsuccessful hatching or followed by algal bloom-induced fish kill.

Prey-predator relationships also affect the size of vendace populations [36,40-42]. Our findings are consistent with a view that the long lasting period of vendace scarcity may be related to changes in fish community structure induced mainly by climatic factors [36]. In Lake Peipsi, a significant increase in the number of the top pelagic predator, pikeperch, preceded the collapse of vendace. By the turn of the decade, 1980/1990, a sharp decline in cool-water vendace population coincided with a 
major increase of warm-water pikeperch (Figure 3). Additionally, a strong negative correlation was found between the landings of pikeperch and vendace in the same and the preceding seven years. Thus, the pikeperch-vendace relationship might be a direct result of predation, vendace being one of the dominant prey fish in the diet of pikeperch in the 1960s [65] until its drastic abundance decrease [66]. Later, the share of vendace in the food of pikeperch has been smaller $[66,67]$. Smelt has been another important prey fish for young pikeperch in Lake Peipsi [66]. However, in recent years, smelt abundance has declined [56]. A sharp decline of small, low trophic-level fishes such as vendace and smelt may have ecosystem-wide impacts through the reduced food supply to larger predator fish.

Over the long term, the fish community of Lake Peipsi has shifted from clean- and cool-water species such as vendace, whitefish and burbot to more pikeperch and bream, which prefer productive warm and turbid waters [58]. According to our correlation analysis, bream catches and vendace catches were negatively correlated, although bream is not a predator of vendace. This may be a reflection of the opposite temperature optima and habitat preferences of these species $[68,69]$. Increase of water temperature, ongoing eutrophication and decrease of water transparency are unfavorable for vendace but favorable for pikeperch and bream.

Concurrently with the decline in Lake Peipsi, vendace has also declined in some Finnish lakes (e.g., Lake Pyhäjärvi and Lake Puulavesi [15-17]), in several lakes in the United Kingdom [19] and in Sweden (Lake Mälaren [18]). Therefore, vendace stocks in a larger area often tend to have similar dynamics [16], suggesting a relationship with climatic factors common to the whole region, where vendace habitats are at the extremes of their geographical range [26]. Nevertheless, in several cases, such as in Finland, the vendace stock has recovered and is abundant [21]. A collapse of the vendace catch in Lake Peipsi was observed nearly 30 years ago. Although small-bodied fish with short lifespans supposedly recover quickly after such a collapse $[70,71]$, the abundance of vendace in Lake Peipsi is still relatively low; in just a few years, its abundance and yields have been somewhat higher (Figure 3). This can be related to its short lifespan, top-down interactions and continuing high fishing pressure combined with heat waves, cyanobacterial blooms and low oxygen concentrations (increasing the deposition of algal remains on the vendace spawning grounds [23]); these are all more frequently observed phenomena in Lake Peipsi [57,72]. This impairment of spawning areas renders the recovery of the vendace population uncertain. Moreover, the increased abundance of predatory fish (e.g., perch and pikeperch) may be a crucial factor preventing vendace recovery. Although vendace can be a successful invader in northern areas [73,74] and its population may recover in northern habitats, such as in Finland [21], population recovery in the southern part of its distribution area may be extremely difficult to obtain, as evidenced in the present study of Lake Peipsi. The data for shallow Lake Peipsi indicate that the continued cultural eutrophication amplifies the effect of warm temperature extremes [57]. Eutrophication has caused deterioration of water quality and adverse changes in the whole ecosystem [75] (e.g., excessive growth of algae, increased cyanobacterial blooms, low oxygen concentrations in water during night, increased sedimentation on spawning grounds and fish kills). There have been several fish kills in the hot summers during heat waves in recent years [57,72]. Although vendace stocks may often decline concurrently in a larger area, the recovery process may vary significantly in different regions and in lakes with different morphometric characteristics (in shallow and deep lakes).

\section{Conclusions}

Heat waves in summer and extreme ice conditions during the winter may have profound detrimental effects on cool-water, autumn-spawning, short-lived fish such as vendace in shallow and polymictic lakes situated in the north temperate region. In such lakes, there is no cool-water and oxygen-rich refuge in summer, and wave action can harm fish eggs on the spawning grounds in mild winters without permanent ice cover. Although our study focused on vendace, our findings are relevant within the context of conservation of similarly sensitive cool-water adapted fish species, such as whitefish, burbot and smelt, in a changing climate. We propose that fish species on the edge 
of their southern range in the northern hemisphere are likely the most vulnerable to the predicted future changes in climate, involving an enhanced frequency and intensity of warm temperature extremes [76] and less ice cover in lakes [77]. However, for conservation of temperature-sensitive fish species currently in decline in northern European freshwater ecosystems, we can likely diminish human pressures (e.g., cultural eutrophication and overfishing) but locally not climate warming.

Author Contributions: All authors contributed substantially to conceptualization, methodology, statistical analysis, investigation and interpretation of data. All authors have read and agreed to the published version of the manuscript.

Funding: This research received no external funding.

Acknowledgments: The authors would like to thank all the people who participated in the field work to collect data. This study was supported by the Estonian Research Council (PRG 1574). The authors thank A.M. Poulsen for editing the manuscript.

Conflicts of Interest: The authors declare no conflict of interest.

\section{References}

1. Allan, J.D.; Abell, R.; Hogan, Z.; Revenga, C.; Taylor, B.W.; Welcomme, R.L.; Winemiller, K. Overfishing of Inland Waters. Biosci. 2005, 55, 1041-1051. [CrossRef]

2. Hunt, T.L.; Douglas, J.W.; Allen, M.S.; Gwinn, D.C.; Tonkin, Z.; Lyon, J.; Pickworth, A. Evaluation of population decline and fishing sustainability of the endangered Australian freshwater fish Macquaria australasica. Fish. Manag. Ecol. 2011, 18, 513-520. [CrossRef]

3. Pukk, L.; Kuparinen, A.; Järv, L.; Gross, R.; Vasemägi, A. Genetic and life-history changes associated with fisheries-induced population collapse. Evol. Appl. 2013, 6, 749-760. [CrossRef]

4. Cowx, I.G. Characterisation of inland fisheries in Europe. Fish. Manag. Ecol. 2015, 22, 78-87. [CrossRef]

5. Kidd, K.A.; Blanchfield, P.J.; Mills, K.H.G.; Palace, V.P.; Evans, R.E.; Lazorchak, J.M.; Flick, R.W. Collapse of a fish population after exposure to a synthetic estrogen. Proc. Natl. Acad. Sci. 2007, 104, 8897-8901. [CrossRef]

6. E Werner, E.; Gilliam, J.F. The Ontogenetic Niche and Species Interactions in Size-Structured Populations. Annu. Rev. Ecol. Syst. 1984, 15, 393-425. [CrossRef]

7. Ohlberger, J.; Langangen, Ø.; Edeline, E.; Claessen, D.; Winfield, I.J.; Stenseth, N.C.; Vøllestad, L.A. Stage-specific biomass overcompensation by juveniles in response to increased adult mortality in a wild fish population. Ecology 2011, 92, 2175-2182. [CrossRef]

8. Shelton, A.O.; Mangel, M. Fluctuations of fish populations and the magnifying effects of fishing. Proc. Natl. Acad. Sci. USA 2011, 108, 7075-7080. [CrossRef]

9. Jeppesen, E.; Mehner, T.; Winfield, I.J.; Kangur, K.; Sarvala, J.; Gerdeaux, D.; Rask, M.; Malmquist, H.J.; Holmgren, K.; Volta, P.; et al. Impacts of climate warming on the long-term dynamics of key fish species in 24 European lakes. Hydrobiology 2012, 694, 1-39. [CrossRef]

10. Herschy, R.W.; Wohlfarth, B.; Kangur, K.; Kangur, A.; Raukas, A.; Pettersson, K.; Davis, J.; Carling, P.; Bengtsson, L. Peipsi Lake in Estonia/Russia. In Encyclopedia of Solid Earth Geophysics; Springer Science and Business Media LLC: Berlin/Heidelberg, Germany, 2012; pp. 596-607.

11. Durant, J.M.; Hjermann, D.; Ottersen, G.; Stenseth, N.C. Climate and the match or mismatch between predator requirements and resource availability. Clim. Res. 2007, 33, 271-283. [CrossRef]

12. Jeppesen, E.; Meerhoff, M.; Davidson, T.A.; Trolle, D.; Søndergaard, M.; Lauridsen, T.L.; Beklioğlu, M.; Brucet, S.; Volta, P.; González-Bergonzoni, I.; et al. Climate change impacts on lakes: An integrated ecological perspective based on a multi-faceted approach, with special focus on shallow lakes. J. Limnol. $2014,73$. [CrossRef]

13. Woolway, R.I.; Dokulil, M.T.; Marszelewski, W.; Schmid, M.; Bouffard, D.; Merchant, C.J. Warming of Central European lakes and their response to the 1980s climate regime shift. Clim. Chang. 2017, 142, 505-520. [CrossRef]

14. Olden, J.D.; Hogan, Z.S.; Zanden, M.J.V. Small fish, big fish, red fish, blue fish: Size-biased extinction risk of the world's freshwater and marine fishes. Glob. Ecol. Biogeogr. 2007, 16, 694-701. [CrossRef]

15. Helminen, H.; Sarvala, J. Population regulation of vendace (Coregonus albula) in Lake Pyhajarvi, southwest Finland. J. Fish Boil. 1994, 45, 387-400. [CrossRef] 
16. Marjomäki, T.J.; Auvinen, H.; Helminen, H.; Huusko, A.; Sarvala, J.; Valkeajärvi, P.; Viljanen, M.; Karjalainen, J. Spatial synchrony in the inter-annual population variation of vendace (Coregonus albula (L.)) in Finnish lakes. Ann. Zool. Fenn. 2004, 41, 225-240.

17. Marjomäki, T.J.; Urpanen, O.; Karjalainen, J. Two-year cyclicity in recruitment of a fish population is driven by an inter-stage effect. Popul. Ecol. 2014, 56, 513-526. [CrossRef]

18. Nyberg, P.; Bergstrand, E.; Degerman, E.; Enderlein, O. Recruitment of Pelagic Fish in an Unstable Climate: Studies in Sweden's Four Largest Lakes. Ambio 2001, 30, 559-564. [CrossRef]

19. Elliott, J.A.; Bell, V.A. Predicting the potential long-term influence of climate change on vendace (Coregonus albula) habitat in Bassenthwaite Lake, U.K. Freshw. Boil. 2010, 56, 395-405. [CrossRef]

20. Winfield, I.J.; Adams, C.E.; Bean, C.W.; Durie, N.C.; Fletcher, J.M.; Gowans, A.R.; Harrod, C.; James, J.B.; Lyle, A.A.; Maitland, P.S.; et al. Conservation of the vendace (Coregonus albula), the U.K.'s rarest freshwater fish. Adv. Limnol. 2012, 63, 547-559.

21. Valkeajärvi, P.; Auvinen, H.; Riikonen, R. Vendace stocks 2009-2010. Index of Density for Vendace, Perch, Smelt, Whitefish and Roach Almost for 100 Finnish lakesace Stocks 2009-2010. Available online: https: //jukuri.luke.fi/bitstream/handle/10024/531246/rks2010_12.pdf?sequence=1 (accessed on 1 September 2020).

22. Karjalainen, J.; Auvinen, H.; Helminen, H.; Arjomäki, T.J.; Niva, T.; Sarvala, J.; Vilhanen, M. Unpredictability of fish recruitment: Interannual variation in young-of-the-year abundance. J. Fish Boil. 2000, 56, 837-857. [CrossRef]

23. Winfield, I.J.; Fletcher, J.M.; James, J.B. Conservation ecology of the vendace (Coregonus albula) in Bassenthwaite Lake and Derwent Water, U.K. Ann. Zool. Fenn. 2004, 41, 155-164.

24. Auvinen, H. Factors affecting the year-class strength of vendace (Coregonus albula (L.)) in Lake Pyhäjärvi (Karelia, SE-Finland). Finn. Fish. Res. 1988, 9, 235-243.

25. Tapaninen, M.; Keskinen, T.; Marjomäki, T.J. The seasonal final temperature preferenda of immature vendace, Coregonus albula (L.). Arch. Hydrobiol. Spec. Issues Advanc. Limnol. 1998, 50, 131-141.

26. Sarvala, J.; Helminen, H.; Auvinen, H. Portrait of a flourishing freshwater fishery: Pyhäjärvi, a lake in SW-Finland. Boreal Env. Res. 1999, 3, 329-345.

27. Dembiński, W. Vertical distribution of vendace Coregonus albula L. and other pelagic fish species in some Polish lakes. J. Fish Boil. 1971, 3, 341-357. [CrossRef]

28. George, D.G.; Bell, V.A.; Parker, J.; Moore, R.J. Using a 1-D mixing model to assess the potential impact of year-to-year changes in weather on the habitat of vendace (Coregonus albula) in Bassenthwaite Lake, Cumbria. Freshw. Boil. 2006, 51, 1407-1416. [CrossRef]

29. Ohlberger, J.; Mehner, T.; Staaks, G.; Hölker, F. Temperature-related physiological adaptations promote ecological divergence in a sympatric species pair of temperate freshwater fish, Coregonusspp. Funct. Ecol. 2008, 22, 501-508. [CrossRef]

30. Ohlberger, J.; Mehner, T.; Staaks, G.; Hölker, F. Is ecological segregation in a pair of sympatric coregonines supported by divergent feeding efficiencies? Can. J. Fish. Aquat. Sci. 2008, 65, 2105-2113. [CrossRef]

31. Mehner, T.; Busch, S.; Helland, I.P.; Emmrich, M.; Freyhof, J. Temperature-related nocturnal vertical segregation of coexisting coregonids. Ecol. Freshw. Fish 2010, 19, 408-419. [CrossRef]

32. Potapova, O.I. Large Vendace Coregonus Albula L.; Nauka: Leningrad, Russia, 1978.

33. Tuvikene, L.; Saat, T. Vendace, Coregonus albula (L.). In Fishes of Estonia; Ojaveer, E., Pihu, E., Saat, T., Eds.; Estonian Academy Publishers: Tallinn, Estonia, 2001; pp. 114-120.

34. Yefimova, A.I. Vendace in Lake Peipsi. In Hydrobiology and fisheries of Lake Peipsi-Pskov; Pihu, E., Mäting, A., Eds.; Valgus: Tallinn, Estonia, 1966; pp. 140-174.

35. Viljanen, M. Biology, propagation, exploitation and management of vendace (Coregonus albula L.) in Finland. Arch. Hydrobiol. Spec. Issues Advanc. Limnol. 1986, 22, 73-97.

36. Auvinen, H. Intra- and interspecific factors in the dynamics of vendace (Coregonus albula (L.)) populations. Finn. Fish. Res. 1994, 15, 49-58.

37. Sandström, A.; Ragnarsson-Stabo, H.; Axenrot, T.; Bergstrand, E. Has climate variability driven the trends and dynamics in recruitment of pelagic fish species in Swedish Lakes Vänern and Vättern in recent decades? Aquat. Ecosyst. Heal. Manag. 2014, 17, 349-356. [CrossRef]

38. Ventelä, A.-M.; Kirkkala, T.; Lendasse, A.; Tarvainen, M.; Helminen, H.; Sarvala, J. Climate-related challenges in long-term management of Säkylän Pyhäjärvi (SW Finland). Hydrobiology 2010, 660, 49-58. [CrossRef] 
39. Helminen, H.; Sarvala, J.; Karjalainen, J. Patterns in vendace recruitment in Lake Pyhajarvi, south-west Finland. J. Fish Boil. 1997, 51, 303-316. [CrossRef]

40. Heikinheimo, O. Effect of predation on the low-density dynamics of vendace: Significance of the functional response. Can. J. Fish. Aquat. Sci. 2001, 58, 1909-1923. [CrossRef]

41. Valkeajärvi, P.; Marjomäki, T.J. Perch (Perca fluviatilis) as a factor in recruitment variations of vendace (Coregonus albula) in lake Konnevesi, Finland. Ann. Zool. Fenn. 2004, 41, 329-338.

42. Karjalainen, J.; Ruokonen, T.J.; Marjomäki, T.J.; Martikainen, A.; Pursiainen, M.; Sarvala, J.; Tarvainen, M.; Ventelä, A.-M. Predation by signal crayfish Pacifastacus leniusculus on fish eggs and its consequences for coregonid recruitment. J. Fish Boil. 2015, 86, 651-667. [CrossRef]

43. Clarke, S.J. Adapting to Climate Change: Implications for Freshwater Biodiversity and Management in the UK. Freshw. Rev. 2009, 2, 51-64. [CrossRef]

44. Woodward, G.; Perkins, D.M.; Brown, L.E. Climate change and freshwater ecosystems: Impacts across multiple levels of organization. Philos. Trans. R. Soc. B: Boil. Sci. 2010, 365, 2093-2106. [CrossRef]

45. Karjalainen, J.; Keskinen, T.; Pulkkanen, M.; Marjomäki, T.J. Climate change alters the egg development dynamics in cold-water adapted coregonids. Environ. Boil. Fishes 2014, 98, 979-991. [CrossRef]

46. Stockwell, J.D.; Doubek, J.P.; Adrian, R.; Anneville, O.; Carey, C.C.; Carvalho, L.; Domis, L.N.D.S.; Dur, G.; Frassl, M.A.; Grossart, H.; et al. Storm impacts on phytoplankton community dynamics in lakes. Glob. Chang. Boil. 2020, 26, 2756-2784. [CrossRef]

47. Turner, M.; Calder, W.J.; Cumming, G.S.; Hughes, T.P.; Jentsch, A.; LaDeau, S.L.; Lenton, T.M.; Shuman, B.N.; Turetsky, M.R.; Ratajczak, Z.; et al. Climate change, ecosystems and abrupt change: Science priorities. Philos. Trans. R. Soc. B Boil. Sci. 2020, 375, 20190105. [CrossRef]

48. Jaagus, J.; Sepp, M.; Tamm, T.; Järvet, A.; Mõisja, K. Trends and regime shifts in climatic conditions and river runoff in Estonia during 1951-2015. Earth Syst. Dyn. 2017, 8, 963-976. [CrossRef]

49. Kotta, J.; Herkül, K.; Jaagus, J.; Kaasik, A.; Raudsepp, U.; Alari, V.; Arula, T.; Haberman, J.; Järvet, A.; Kangur, K.; et al. Linking atmospheric, terrestrial and aquatic environments: Regime shifts in the Estonian climate over the past 50 years. PLoS ONE 2018, 13, e0209568. [CrossRef]

50. Kangur, K.; Möls, T. Changes in spatial distribution of phosphorus and nitrogen in the large north-temperate lowland Lake Peipsi (Estonia/Russia). Hydrobiology 2008, 599, 31-39. [CrossRef]

51. Fink, G.; Burke, S.; Simis, S.G.H.; Kangur, K.; Kutser, T.; Mulligan, M. Management Options to Improve Water Quality in Lake Peipsi: Insights from Large Scale Models and Remote Sensing. Water Resour. Manag. 2018, 34, 1-14. [CrossRef]

52. Jaani, A. The location, size and general characterisation of Lake Peipsi and its catchment area. In Lake Peipsi: Meteorology, Hydrology, Hydrochemistry; Nõges, T., Ed.; Sulemees Publishers: Tartu, Estonia, 2001; pp. 10-17.

53. Estonian Environment Agency 2019/2020 aasta talv on esimene talv alates vaatlusajaloo algusest 1921. aastal kui Peipsil püsivat jääkatet ei tekkinud 2020. Available online: www.keskkonnaagentuur.ee (accessed on 28 April 2020).

54. Vollenweider, R.A.; Kerekes, J. Eutrophication of Waters. Monitoring, Assessment and Control; OECD: Paris, France, 1982.

55. Kangur, A.; Kangur, P.; Pihu, E.; Vaino, V.; Tambets, M.; Krause, T.; Kangur, K. Kalad ja kalandus. In Peipsi; Haberman, J., Timm, T., Raukas, A., Eds.; Eesti Loodusfoto Publishers: Tallinn, Estonia, 2008; pp. 317-340.

56. Tammiksaar, E.; Kangur, K. Fish and fishing in Lake Peipsi (Estonia/Russia) since 1851: Similarities and differences between historical and modern times. J. Great Lakes Res. 2020, 46, 862-869. [CrossRef]

57. Kangur, K.; Kangur, P.; Ginter, K.; Orru, K.; Haldna, M.; Möls, T.; Kangur, A. Long-term effects of extreme weather events and eutrophication on the fish community of shallow Lake Peipsi (Estonia/Russia). J. Limnol. 2013, 72, e30. [CrossRef]

58. Kangur, K.; Park, Y.-S.; Kangur, A.; Kangur, P.; Lek, S. Patterning long-term changes of fish community in large shallow Lake Peipsi. Ecol. Model. 2007, 203, 34-44. [CrossRef]

59. OnlineDoc 9.2.; SAS Institute Inc: Cary, NC, USA, 2008.

60. Möls, T. Linear Statistical Methods for Estonian Freshwater Waterbodies; Estonian Naturalists' Society: Tartu, Estonia, 2005.

61. Hou, X.-G.; Siveter, D.J.; Aldridge, R.J.; Cong, P.-Y.; Gabbott, S.E.; Ma, X.; Purnell, M.A.; Williams, M. Algae; Wiley: Hoboken, NJ, USA, 2017; pp. 39-47. 
62. Dahlke, F.T.; Wohlrab, S.; Butzin, M.; Pörtner, H.-O. Thermal bottlenecks in the life cycle define climate vulnerability of fish. Science 2020, 369, 65-70. [CrossRef]

63. Laugaste, R.; Haberman, J. Seasonality of zoo- and phytoplankton in Lake Peipsi (Estonia) as a function of water temperature. Proc. Estonian Acad. Sci. Biol. Ecol. 2005, 54, 18-39.

64. Helminen, H.; Sarvala, J.; Hirvonen, A. Growth and food consumption of vendace (Coregonus albula (L.)) in Lake Pyhäjärvi, SW Finland: A bioenergetics modeling analysis. Hydrobiology 1990, 200, 511-522. [CrossRef]

65. Pihu, E. The Importance of Pike, Perch, Pikeperch and Burbot as Biological Control in Lake Peipsi-Pskov; Valgus: Tallinn, Estonia, 1966; Volume 4.

66. Kangur, A.; Kangur, P. The condition, length and age distribution of pikeperch, Stizostedion lucioperca (L.) in Lake Peipsi. Hydrobiology 1996, 338, 179-183. [CrossRef]

67. Kangur, A.; Kangur, P. Diet composition and size-related changes in the feeding of pikeperch, Stizosteion lucioperca (Percidae) and pike, Esox lucius (Esocidae) in the Lake Peipsi (Estonia). Ital. J. Zool. 1998, 65, 255-259. [CrossRef]

68. Lehtonen, H. Potential effects of global warming on northern European freshwater fish and fisheries. Fish. Manag. Ecol. 1996, 3, 59-71. [CrossRef]

69. Froese, R.; Pauly, D. (Eds.) FishBase. World Wide Web Electronic Publication; FishBase Mirror: Stockholm, Sweden, 2019.

70. McCullough, D.R.; Reynolds, J.D.; Mace, G.M.; Redford, K.H.; Robinson, J.G. Conservation of Exploited Species. J. Wildl. Manag. 2003, 67, 656. [CrossRef]

71. Reynolds, J.D. Life histories and extinction risk. In Macroecology; Blackburn, T.M., Gaston, K.J., Eds.; Blackwell: Oxford, UK, 2003; pp. 195-217.

72. Kangur, K.; Kangur, A.; Kangur, P.; Laugaste, R. Fish kill in Lake Peipsi in summer 2002 as a synergistic effect of cyanobacterial bloom, high temperature and low water level. Proc. Estonian Acad. Sci. Biol. Ecol. 2005, $54,67-80$.

73. Liso, S.; Gjelland, K.Ø.; Reshetnikov, Y.S.; Amundsen, P.-A. A planktivorous specialist turns rapacious: Piscivory in invading vendace Coregonus albula. J. Fish Boil. 2010, 78, 332-337. [CrossRef]

74. Liso, S.; Gjelland, K.Ø.; Amundsen, P. Resource partitioning between pelagic coregonids in a subarctic watercourse following a biological invasion. J. Ichthyol. 2013, 53, 101-110. [CrossRef]

75. Kangur, M.; Kangur, K.; Laugaste, R.; Punning, J.-M.; Möls, T. Combining limnological and palaeolimnological approaches in assessing degradation of Lake Pskov. Hydrobiology 2007, 584, 121-132. [CrossRef]

76. Pachauri, R.K.; Allen, M.R.; Barros, V.R.; Broome, J.; Cramer, W.; Christ, R.; Church, J.A.; Clarke, L.; Dahe, Q.; Dasgupta, P.; et al. Climate Change 2014: Synthesis Report. Contribution of Working Groups I, II and III to the Fifth Assessment Report of the Intergovernmental Panel on Climate Change; Pachauri, R.K., Meyer, L., Eds.; IPCC: Geneva, Switzerland, 2014; p. 151. ISBN 978-92-9169-143-2.

77. Woolway, R.I.; Kraemer, B.M.; Lenters, J.D.; Merchant, C.J.; O’Reilly, C.M.; Sharma, S. Global lake responses to climate change. Nat. Rev. Earth Environ. 2020. [CrossRef]

(C) 2020 by the authors. Licensee MDPI, Basel, Switzerland. This article is an open access article distributed under the terms and conditions of the Creative Commons Attribution (CC BY) license (http://creativecommons.org/licenses/by/4.0/). 